\title{
Satellite-Based Observation Snowmelt Runoff Modelling insight of Climate Changes in an Alpine Chitral River basin, Pakistan
}

\author{
iqra Munir ${ }^{1}$, Jianzhong $\mathrm{Lu}^{1}$, Xiaoling Chen ${ }^{1}$, Hassan Waqas ${ }^{2}$, Rehan $\mathrm{Khan}^{3}$, B.G. Mousa ${ }^{4}$, \\ Hussein A. Mohasseb ${ }^{1}$, and Abdur Raziq ${ }^{5}$ \\ ${ }^{1}$ Wuhan University \\ ${ }^{2}$ China University of Geosciences \\ ${ }^{3}$ Central South University \\ ${ }^{4}$ Al-Azhar University \\ ${ }^{5}$ University of Peshawar
}

January 20, 2022

\begin{abstract}
Snowmelt runoff is an important element of the hydrological cycle as global warming and climate change are causing the retreat of glaciers particularly in the northern region of Pakistan. These climatic variations cause significant changes in snow and the glaciated environment causing an influence on the Indus river runoff contributed by Chitral Basin. The daily discharge of the Chitral River Basin (CRB) over the Hindukush area is simulated in this study using the Snowmelt Runoff Model (SRM) model under realistic concentration pathways and climate change scenarios in the period from 2011 to 2020. The daily temperature, precipitation, and snow cover data were used as input variables to determine discharge by using SRM. The results of the simulation showed that snow cover is sensitive to climate change, particularly when there is an increase in temperature. The Coefficient of determination (R2) values indicate that SRM is good for daily runoff simulations in combination with MODISderived Snow-Covered Area (SCA) and can be optimized for long-term runoff simulations in the CRB. The results of the model simulation showed that the SRM composite reliability values were 0.83-0.91 (R2) in the period from 2011 to 2020 and the snow melting is increasing with respect to time and rising temperatures. The results revealed that the sensitivity of climatic changes, particularly temperature and precipitation fluctuations from north to south, is a major factor in the spatiotemporal melting of snow over the years. The model calculations technique assists effective water resource management, promoting environmental preservation as well as community economic prosperity.
\end{abstract}

\section{Hosted file}

Manuscript.pdf available at https://authorea.com/users/456364/articles/553442-satellitebased-observation-snowmelt-runoff-modelling-insight-of-climate-changes-in-an-alpinechitral-river-basin-pakistan 